\title{
粉末治金プロセスによる製造技術とその材料評侕の新展開 New Developments in Manufacturing Technology and Its Material Evaluation via Powder Metallurgical Processes
}

\author{
伊藤 孝至 \\ Takashi ITOH \\ 名古屋大学 \\ Nagoya University
}

\begin{abstract}
本協会の分科会の一つである「技術・品質評価委員会」で は，粉末治金プロセスに関連する制御技術や製品の定量評価 技術全般をテーマとして, 研究開発の触発，実操業の制御技 術への還元，および基礎知識の集約や新たな問題の顕在化を 可能にする有益なものになることを願って過去 12 回の講演 特集を企画して参りました。平成 28 年度春季大会における 13 回目の講演特集では，「粉末治金プロセスによる製造技術 とその材料評価の新展開」を企画いたしました，本講演特集 は，基礎から応用までを含む貴重な研究成果の講演（招待講 演 4 件抒よび研究発表 12 件の計 16 件）が 4 つのセッション に分かれて行われましたが，会場は聴衆者の座席を追加する 必要がでた程の盛況ぶりでした。
\end{abstract}

以下に講演特集として発表がありました研究内容について 簡単に紹介します。

○第 1 セッションにおける講演内容

大同特殊鋼の山浦氏らは，ガス噴霧ノズルの形状が噴霧ガ スジェットに及ほすす影響について発表しました。 トヨタ自動 車の中谷氏による招待講演では, 充填直前までに粉に与える 動作の履歴に起因する流動性変動に関する実証実験と，それ を踏まえた高精度充填システムの開発についてご講演頂きま した，東京都立産業技術センターの岩岡氏らによる招待講演 では，金型圧粉に扔ける各種金属粉末圧粉体の拔出し易さを 定量的に表す式を提案し評価する方法についてご講演頂きま した。トヨタ中研の三宅氏らは, 開発した $\mathrm{Cu}, \mathrm{Ni}$ フリーの 燒結鋼のミクロ組織制御による高強度高勒性化について発表 しました.

○第 2 セッションに打ける講演内容

名古屋大学の小橋氏による招待講演では，化学反応とその 反応熱を利用・制御したポーラス金属の合成プロセス拈よび 気孔構造制御（メゾ構造制御）に関する研究成果についてご 講演頂きました。産総研の清水氏による招待講演では, ポリ ビニールアルコールを水溶性バインダーとして用いた粉末治 金プロセスによる発泡金属の作製法の紹介と，高気孔多孔質 ステンレス鋼の作製とその機能評価についてご講演頂きまし た．岡山大学の岸本氏らは，固相発泡による $\mathrm{Li}$ 又は $\mathrm{Ag}$ 添加 した $\mathrm{ZnO}$ の高温圧力センサーを作製し，そのセンサーの素
子性能について発表しました，富山大学の砂田氏らは，各種 ステンレス鋼（SUS316抢よびSUS444）に用いる Ni系ろう 材の腐食特性を電気化学的に調査した結果について発表しま した.

○第 3 セッションにおける講演内容

立命館大学の長野氏らは，押出焼結成形をすることでAZ91D マグネシウム合金の調和組織制御材料を作製し，その組織と 機械的特性についての検討結果を発表しました，立命館大学 の藤木氏らは, 調和組織制御された SUS304L ステンレス鋼 の変形に及ぼすひずみ速度の影響について発表しました，大 阪大学のShen 氏らは，粉末治金プロセスによって作製した 純 $\mathrm{Mg}$ 中の 3 時間 $500{ }^{\circ} \mathrm{C}$ 熱处理前後における引張双晶の安定 性についての調查結果を発表しました，大阪大学のChen 氏 らは, カーボンナノチューブやアルミナナノ粒子を添加した アルミニウム基複合材料を作製し，それらの機械的特性につ いて発表しました。

○第 4 セッションにおける講演内容

リコーの佐々木氏らは，インクジェット技術を用いて樹脂 コーティングした各種粉末を積層造形して既存の焼結プロセ スと組み合わせる技術について発表しました．富士ダイスの 内藤氏らは，超硬合金にレーザー積層造形技術を適用して，

積層造形後の HIP 処理の有無による機械的特性などの比較 について発表しました。卅大学の森川氏らは，アルミナ粒 子を均一分散させた $\mathrm{Mg}$ 層とアルミナ粒子を含まない $\mathrm{Mg}$ 層 を交互に積層した成形体を作製し，密度や機械的特性の調査 結果を発表しました。 大阪大学の Sun 氏らは, 選択的にレー ザーで溶解して作製した Ni-Mo 合金中に形成された単結晶 に近い結晶組織に関して発表しました。

以上，粉末治金プロセスを用いた製造技術および製品の定 量評価に関連する様々な材料や技術を対象とした基礎から応 用までを含む非常に有意義な講演特集とすることができまし た。な扔，本講演特集で発表された研究の一部は「粉体㧍よ び粉末治金」平成 29 年 2 月号において講演特集号として揭 載が予定されています。最後に, 貴重な成果についてご講演 いただいた方々ならびに活発な議論にご参加頂いた方々に, 本講演特集の企画者として厚く御礼申し上げます. 